\title{
TRIPS-Round II: Should Users Strike Back?
}

\author{
Rochelle Cooper Dreyfuss $\dagger$
}

The TRIPS Agreement,' the instrument of the General Agreement on Tariffs and Trade (GATT) governing intellectual property protection at the international level, is structured to directly protect the rights of intellectual property holders. It does little, however, to explicitly safeguard the interests of those who seek to use protected works. In some ways, this structure is not surprising. Because the free traders who negotiated the GATT worked in an environment in which the core concern, reducing market barriers, was viewed as producing (at least in the long term) unmitigated welfare gains, they were not likely to appreciate the social importance, in TRIPS, of balancing proprietary interests against public access needs. Moreover, to the extent that the United States was a prime mover in the Uruguay Round, its intent was to ease U.S. trade deficits by creating broader exclusive markets for intellectual products, a goal with rather a scant role for user rights. ${ }^{2}$ As a result, the TRIPS Agreement specifies levels of protection that can be exceeded, but not easily diminished. User interests are largely left to domestic practice through provisions like the famous (now notorious) "three-part" tests, which permit members to create limited derogations from protection, but only so long as they do not unreasonably conflict with normal exploitation of the protected work or unreasonably prejudice the right holder (taking into account, in the case of patents, the interests of third parties). ${ }^{3}$

It is rapidly becoming evident, however, that there are problems with a bifurcated system that, in effect, permits (encourages) members to expand intellectual property rights, but which makes them subject to challenge before the WTO when they reduce any of the incidents of protection. Developing countries are the most obviously vulnerable. Because their obligation to protect intellectual property arises solely out of WTO

$\dagger$ Pauline Newman Professor of Law, New York University School of Law. I would like to thank the Filomen D'Agostino and Max E. Greenberg Research Fund for its financial support, and Graeme Dinwoodie, Harry First, Pam Samuelson, and David Vaver for comments on an earlier draft.

1 Agreement on Trade-Related Aspects of Intellectual Property Rights (Apr 15, 1994) (TRIPS), reprinted in The Legal Texts: Results of the Uruguay Round of Multilateral Trade Negotiations Annex 1C at 321-53 (Cambridge 1994).

2 See Susan K. Sell, Private Power, Public Law: The Globalization of Intellecual Property 75 95 (Cambridge 2003) (discussing the role of industry associations in the formation of the U.S. policy linking international trade to intellectual property protection).

3 See, for example,TRIPS Arts 13,30 at 326,334 (cited in note 1) (allowing domestic governments to create certain limited exceptions to the exclusive property rights recognized under the Agreement). See also id Art 31 at 334 , on compulsory licensing. 
membership, and not from intrinsic economic conditions, the impact on these countries has been especially severe, raising the cost of end products (such as essential medicines and educative materials) without providing significant compensatory benefits in the form of new sources of revenue.

Somewhat less apparent, but no less important, is the effect of this asymmetric approach on the developed world. Knowledge production is a cumulative enterprise; the storehouse of information does not grow unless creators have the freedom to learn from, and build on, earlier work. Especially in sectors engaged in generating fundamental cultural and scientific advances that are traditionally sources of important spillover benefits, the inability to control the rising costs of intellectual inputs is potentially chilling. Nor is it optimal for international agreements to freeze the law of innovation when the output and organization of creative enterprises change over time. ${ }^{4}$

This Essay is mainly designed to make a case for using the next Round of GATT negotiations to add explicit user rights to the Agreement. It ends with a short section that suggests sources for these rights and begins an exploration of what they should comprise.

\section{THE CASE FOR USER RIGHTS}

The problem of the "one-way ratchet" at the international level has been identified by others, and at least two moves to correct the problem within the existing GATT framework have been suggested. One is to stress the aspirational sections of TRIPS. Article 7, for example, refers to "the mutual advantage of producers and users of technological knowledge"; it also speaks of a "balance of rights and obligations" and "social and economic welfare." Article 8(1) talks of public health and promoting "the public interest in sectors of vital importance."

4 See Graeme Dinwoodie and Rochelle Dreyfuss, Preserving the Public Domain of Science under International Law, in Keith Maskus and J.H. Reichman, eds, International Public Goods and Transfer of Technology under a Globalized Intellectual Property Regime (forthcoming 2004) (discussing whether and how TRIPS can be read with fluidity to accommodate innovation and changes in the production of information).

5 There are other areas where trade and intellectual property specialists have differing perceptions, including the benefits of one-way pressures. See Andreas F. Lowenfeld, Public Controls on International Trade $\$ 2.42$ (Matthew Bender 2d ed 1983) (discussing the effect of most-favored-nation clauses); Rochelle Cooper Dreyfuss and Andreas F. Lowenfeld, Two Achievements of the Uruguay Round: Putting TRIPS and Dispute Settlement Together, 37 Va J Intl L 275, 275-81 (1997) (discussing the effect of protectionism).

6 TRIPS Art 7 at 324 (cited in note 1).

7 Id Art 8(1) at 324. See also Ruth Okediji, Toward an International Fair Use Doctrine, 39 Colum J Transnatl L 75, 167-68 (2000) (describing the exceptions to strong property protection allowed under Articles 7 and 8 and suggesting the use of these exceptions as an approach to developing an international fair use doctrine). 
When TRIPS cases have gone to WTO dispute resolution, panels have, in fact, referred to these provisions favorably. ${ }^{*}$ However, experience with the aspirational aspects of other constitutive agreements suggests that this approach has its limits. Institutionally, dispute resolution panels and the Appellate Body are, at best, courts. They are not well positioned to engage in the kind of lawmaking that can forge delicate balances among interests and create equilibria durable over a range of factual circumstances." Infusing content into precatory statements is, in any event, difficult, especially when antithetical interests are explicitly codified. As experience demonstrates, the bite of such provisions tends to ebb and flow over time." The sort of long-term investments that are required to fund innovation cannot easily tolerate a legal environment that fluctuates so readily.

Illustrative is the aftermath of the Doha negotiations, which (in part) addressed the problem of providing essential medicines to less developed countries. These countries are experiencing a health crisis and can, accordingly, take advantage of Articles 7 and 8 , as well as a provision of the Agreement that permits compulsory licensing for health needs." However, there is a proviso in the compulsory licensing section permitting only compulsory licensing that is "predominantly for the supply of the domestic market of the Member." If read to apply to actions taken to deal with medical issues, this proviso means that members that lack the facilities to manufacture pharmaceuticals cannot provide for their citizenry.

8 See, for example, WTO Dispute Settlement Panel, Canada-Patent Protection of Pharmaceutical Products, WT/DS114/R, § 7.26 at 154 (Mar 17, 2000), online at http://www.wto.org/english/ tratop_e/dispu_e/7428d.pdf (visited Jan 12, 2004) (noting that, when interpreting Article 30 of the TRIPS Agreement on derogations, the goals and limitations stated in Articles 7 and 8.1 must be borne in mind).

9 Compare Brief of Amicus Curiae United States, Duke University v Madey, Civil Action No 02-1007, ${ }^{*} 13-17$ (S Ct filed May 2003), online at http:/www.usdoj.gov/osg/briefs/2002/2pet/6invit/ 2002-1007.pet.ami.inv.pdf (visited Jan 12,2004) (suggesting that the Supreme Court is not the appropriate body to balance the interests in shaping the experimental-use defense to patent infringement). The panels are not even standing tribunals; they are assembled ad hoc. See Dreyfuss and Lowenfeld, 37 Va J Intl L at 279 (cited in note 5) (describing the make-up of the Dispute Settlement Board under GATT).

10) The problem of operationalizing aspirational provisions is well illustrated by the debate in the United States over implied rights of action, see, for example, Bivens $v$ Six Unknown Named Agents of Federal Bureau of Narcotics, 403 US 388 (1971) (holding that a plaintiff may recover damages for a violation of his Fourth Amendment rights by federal government officers), and implied remedies, see, for example, Sullivan v Little Hunting Park, Inc, 396 US 229 (1969) (holding that state courts may have to "fashion an effective equitable remedy" for a violation of federal law even if such remedies are not permitted under state law). See generally Richard B. Stewart and Cass $R$. Sunstein, Public Programs and Private Rights, 95 Harv L Rev 1193 (1982) (discussing implied rights of action and administrative remedies).

11 See TRIPS Art 31(b) at 334 (cited in note 1) (stating that the requirement of permission to use patented technology may be waived in cases of national emergency). See also id Art 27(2) at 333 (stating that patentability can be denied to protect health).

12 Id Art 31(f) at 334. 
The Doha meeting ended in November 2001 with a declaration recognizing the gravity of the problem and committing the membership to solving it by the end of 2002. ${ }^{13}$ By that date, Perez Motta, Chair of the TRIPS Council, had indeed proposed a solution. Significantly, however, he did not use the aspirational provisions of Article 7 or 8 to argue that the proviso was inapplicable to health crises. Instead, he proposed that developed countries waive application of the proviso so that countries (such as India and Brazil) with generic drug industries could supply drugs to other members. He also suggested that production could be facilitated by allowing one member of a regional group (such as the African nations) to manufacture for the entire region. ${ }^{14}$ As of this writing in late 2003 , however, proposals along these lines are just beginning to be implemented. Apparently, right holders are reluctant to support an approach that fosters the development of new manufacturing capacity. ${ }^{15}$ Public-regarding precatory language is, in short, unavailing when there are provisions that explicitly support proprietary interests.

A second way to combat the one-way ratchet is to tease a theory of federalism and state autonomy out of the various places (such as the aforementioned three-part tests) where the Agreement defers to member

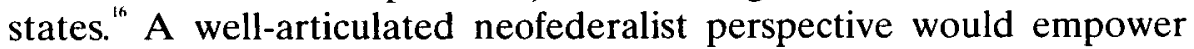
states to protect user interests. ${ }^{17}$ Stripped of the fancy rhetoric, commentators such as Jerry Reichman have played on the same idea to suggest that there is "wiggle room" in TRIPS for nations to ensure that users enjoy access to protected materials."

13 See WTO Ministerial Conference, Declaration on the TRIPS Agreement and Public Health, WT/MIN(01)/DEC/2, $\$ 1,5,6$ (Nov 14, 2001), online at http://www.wto.org/english/thewto_e/ minist_e/min01_e/mindecl_trips_e.htm (visited Jan 12, 2004):

We recognize that WTO Members with insufficient or no manufacturing capacities in the pharmaceutical sector could face difficulties in making effective use of compulsory licensing under the TRIPS Agreement. We instruct the Council for TRIPS to find an expeditious solution to this problem and to report to the General Council before the end of 2002.

14 Council for TRIPS, Implementation of Paragraph 6 of the Doha Declaration on the TRIPS Agreement and Public Health, JOB(02)/217 (Dec 16, 2002), online at http://www.ictsd.org/ministerial/ cancun/docs/TRIPs_para6_16-12-02.pdf (visited Jan 12, 2004) (proposing methods for implementing paragraph 6). See also Council for TRIPS, Decision of 30 August 2003: Implementation of Paragraph 6 of the Doha Declaration on the TRIPS Agreement and Public Health, WT/L/540 (Sept 1,2003), online at http://www.wto.org/english/tratop_e/trips_e/implem_para6_e.htm (visited Jan 12.2004) (waiving member countries' obligations under TRIPS Article 31(f) to manufacture only for a domestic market. allowing the importation of cheaper generics for needy countries).

15 For a history of the negotiation, see Consumer Project on Technology, Patent Exception for Exports to Address Health Needs, online at http://www.cptech.org/ip/wto/p6 (visited Jan 12, 2004).

16 See TRIPS Art 40 at 338 (cited in note 1) (permitting member states to control anticompetitive practices).

17 See, for example, Dinwoodie and Dreyfuss, Preserving the Public Domain (cited in note 4); Shubha Ghosh, The Traditional Terms of the Knowledge Debate, 23 Nw J Intl L \& Bus 3 (2003) (discussing the use of intellectual property law to protect traditional knowledge).

18 J.H. Reichman, From Free Riders to Fair Followers: Global Competition under the TRIPS Agreement, 29 NYU J Intl L \& Polit 11,87-89 (1997) (suggesting that a developing country "seek to 
This idea has also received support from the Appellate Body," but, again, the approach is limited. For one, it requires either that a country have experience with intellectual property protection or sufficient human capital (in the form of legal talent) to codify wiggles into law. Many developing countries lack both. Without adequate counsel, they may choose to meet their TRIPS obligations by simply transcribing its mandates into law. As an example of where this could lead, consider trade secrets: since TRIPS does not mention a right to reverse engineer, transcription would create a level of protection surpassing that found in the United States, where the right to copy is privileged. ${ }^{20}$ It is true that the drafters anticipated this problem: the Agreement requires developed countries to furnish other members with technical assistance, including in the preparation of domestic legislation relating to intellectual property protection. ${ }^{21}$ However, anecdotal evidence (such as the choice of Hilary Rosen, a former chief executive of the Recording Industry Association of America, to draft copyright law for Iraq ${ }^{22}$ ) suggests that the countries in a position to provide assistance do so on their own terms; that is, they help implement highly protectionist regimes, without regard for the actual needs of developing nations.

Another problem is that developing a federalist approach, one that is capable of application in the dispute-settlement environment of TRIPS, requires a thick understanding of institutional structure, capabilities, and design. The WTO is itself immature and includes members who are new to intellectual property protection, to a market-based economy, or even to the rule of law. The European Union's experience with constitutionalizing a theory of federalism demonstrates that developing a coherent vision is

exploit such local autonomy as it retains" under TRIPS and structure its local intellectual property regime to "promote both innovation and competition").

19 WTO Appellate Body, India-Patent Protection for Pharmaceutical and Agricultural Chemical Products, WT/DS50/AB/R, \& VI (Dec 19,1997), online at http://docsonline.wto.org (visited Jan 12, 2004) (holding that Article 1.1 of TRIPS allows member countries to "determine the appropriate method of implementing the provisions of this Agreement" in the context of their domestic legal systems); J.H. Reichman, The TRIPS Agreement Comes of Age: Conflict or Cooperation with the Developing Countries?, 32 Case W Res J Intl L 441, 446 (2000) (explaining that the Appellate Body evinced substantial deference to local law in applying TRIPS).

20) Compare TRIPS Art 39 at 338 (cited in note 1) (setting out minimum requirements for trade secret protection without mention of whether those who independently develop information protected by others as trade secrets are violating intellectual property rights when they use such information), with Uniform Trade Secrets Act $\$ 1,14$ ULA 437,438 (1990) (requiring that trade secrets be acquired through improper means to create liability); Kewanee Oil Co v Bicron Corp, 416 US 470. 476 (1974) (explaining that trade secret law "does not offer protection against discovery by fair and honest means"). See also British Sugar Plc v James Robertson \& Sons, 1996 RPC 281, 291 (UK Ch) (expressing "bafflement" that the UK draftsmen implementing the EU Trademark Directive did not simply copy the language of the directive but instead rewrote it).

21 See TRIPS Art 67 at 350 (cited in note 1).

22 See Andrew Orlowski, RIAA's Rosen 'Writing Iraq Copyright Laws,' The Register (Apr 29, 2003), online at http://www.theregister.co.uk/content/6/30441.html (visited Jan 12, 2004). 
not easy under such circumstances. ${ }^{2}$ Even in the United States, with its long tradition of federalism, views on deference and state autonomy shift over time: periods of great respect for local action give way to closer scrutiny, and vice versa. ${ }^{24}$ Such fluctuations are not consistent with robust and sustained investment in innovation.

In developed countries there are also other dynamics at play. The flexibility that TRIPS gives to member states is couched in terms of the effects that national measures have on the interests of right holders (the three-part tests are examples). As we saw, when the focus is on intellectual property rights, the analysis tends to skew in favor of proprietary concerns. ${ }^{25}$ Furthermore, user interests can be protected by deference to local law only if local lawmakers retain the resolve to promote user values. That resolve can easily dissipate in the welter of international lobbying. In that arena, public choice problems are exacerbated because right holders have so far proven better able than user groups to put their demands before multiple legislatures and international lawmakers. ${ }^{26}$ Once one of these bodies gives in to right-holder demands, other lawmakers are easily forced along, either through explicit reciprocity requirements in the relevant legislation or out of fear that they will relinquish a leadership role in developing world innovation policy. ${ }^{27}$ More generally, as Robert Merges has recently pointed out, there has been a baseline change in intellectual property thinking. Competition was once the norm, and intellectual property rights were regarded as the exception. However, in recent years, "the labor-equals-property principle" has come to dominate, with the result that the proper baseline is to protect all manner of creativity. $^{28}$

23 See, for example, John Vinocur, EU's Draft Constitution: Still Far from Unity, Intl Herald Trib 1 (June 24, 2003) (discussing the difficulty in implementing EU initiatives).

24 See, for example, Jesse H. Choper, Taming Congress's Power under the Commerce Clause: What Does the Near Future Portend?, 55 Ark L Rev 731,731-36 (2003) (discussing the history of congressional action under the Commerce Clause).

25 Compare CCH Canadian Ltd v Law Society of Upper Canada, 4 FC 213, 278-79 (Can Fed Ct 2002) (stating that the interpretation of fair dealing in Canadian copyright law depends on whether it is a user right or a derogation from the copyright holder's interest).

26 See Sell, Private Power, Public Law at 96-100 (cited in note 2) (discussing the influence of private sector actors in the policymaking process).

27 Examples of this dynamic can be found in the Semiconductor Chip Protection Act, 17 USC $\$ 914$ (2000) (extending protection only to nationals of countries that have enacted or are enacting similar protection), and in Europe's database directive, Directive 96/9/EC of the European Parliament and of the Council of 11 March 1996 on the Legal Protection of Databases, 39 Off J Eur Communities (L 77) 20, 24 recital 56 (Mar 27,1996) (specifying that the right applies to databases whose makers are nationals or habitual residents of third countries "only if such third countries offer comparable protection to databases produced by nationals of a Member State").

28 Robert P. Merges, The Uninvited Guest: Patents on Wall Street (UC Berkeley School of Law Public Law and Legal Theory Research Paper No 126, 2003), online at http://papers.ssrn.com/ id $=410900$ (visited Jan 12, 2004). See also L. Ray Patterson and Stanley W. Lindberg, The Nature of Copyright: A Law of Users' Rights 50-51 (Georgia 1991) (discussing copyright's quid pro quo, an exclusive property right in exchange for eventual surrender to the public domain). 
These problems suggest that the user side of the equation requires attention, that the WTO system must begin to recognize substantive maxima on the scope of available protection, ${ }^{20}$ or, as David Vaver has proposed, explicit user rights." Clearly, the hostility to implementing the public-regarding sentiments of the Doha Agreement indicates the difficulty involved in making such a move. However, if Merges is right and baseline expectations have shifted, then the law should adapt to reflect that change. User access did not need specific delineation when it was the background rule; only the exceptionalism of intellectual property rights required express definition. But if the new background is proprietary control, then the exceptionalism of user rights now needs to be embedded into positive law.

The question, then, is how the system should be structured to recognize positive rights. Institutionally, it cannot easily be effectuated through the dispute resolution process. Not all of the jurists on WTO panels and the Appellate Body come from a common law tradition; indeed, as a formal matter, their decisions are not binding in subsequent disputes. ${ }^{31}$ The WTO membership, which comprises countries with a variety of intellectual needs, is thus better suited to the task. Negotiations could be used to air the various interests involved and to identify the situations where clashes are likely to arise. The drafters would have a full panoply of tools available to achieve durable solutions. ${ }^{32}$

Admittedly, it is unusual for new rights to be recognized for the first time at the international level. In most cases, international law incorporates positions that were pioneered in a domestic context. ${ }^{33}$ However, the globalization of intellectual property usage makes TRIPS a place where that tradition could, and should, be broken. Significantly, there is a growing community of users mobilizing for the next Round. ${ }^{34}$ These players have experience with the problems engendered by the current instrument

29 See, for example, Graeme B. Dinwoodie, A New Copyright Order: Why National Courts Should Create Global Norms, $149 \mathrm{U}$ Pa L Rev 469, 510-11 (2000) (suggesting that the WTO as currently constituted does not take sufficient account of "the broader objectives of copyright law").

30 David Vaver, Session 10: Overview Commentary on Balancing Public and Private Interests, in Conference on International Public Goods and Transfer of Technology after the TRIPS Agreement of 1994 (Duke Law School Apr 4-6, 2003), online at http:/www.law.duke.edu/trips/ webcast.html (00:18:30-00:28:50) (visited Jan 12, 2004). See also David Vaver, Copyright Law 171 (Irwin Law 2000) ("User rights are not just loopholes.").

31 See Dinwoodie and Dreyfuss, Preserving the Public Domain (cited in note 4).

32 Compare Pamela Samuelson, The U.S. Digital Agenda at WIPO, 37 Va J Intl L 369 (1997) (describing the roles of various countries and coalitions in negotiating post-TRIPS international agreements aimed at recognizing new intellectual property rights).

33 See Dinwoodie, 149 U Pa L Rev at 492-93 (cited in note 29) (discussing the relationship between domestic copyright regimes and the creation of international copyright law).

34 See, for example, the articles comprising Duke University's Conference on the Public Domain, in 66 L \& Contemp Probs 1 (2003); Yochai Benkler, Coase's Penguin, or, Linux and The Nature of the Firm, 112 Yale L J 369 (2002) (discussing the social movement contributing to the development of Linux). 
and have watched international debates tilt local lawmaking in increasingly protective directions. Thus, they can appreciate not only the substantive benefits of user rights, but also the value of using international codification as a precommitment strategy for nations inundated by right-holder lobbying.

Aside from skepticism about, or hostility to, user rights, opposition to codifying them is largely based on a quasi-contractual view, in which each member is seen as consenting to TRIPS based on its perception of the benefits and costs that flow to it from the GATT as a whole. Under this view, adding user rights would give countries that had "won" with respect to other matters in the GATT additional benefits in the form of increased access to intellectual property (and conversely, it would take advantages away from members that had sacrificed other interests in exchange for the right to market intellectual property). Thus, for example, it is said that the United States relinquished markets in raw and manufactured goods in order to reap profits from creative goods. As a result, it is argued, Africa should not now be allowed to renege on that deal, essentially effecting a transfer of wealth, by gaining access to patented pharmaceuticals in violation of the express terms of the current Agreement.

There are several flaws in this analysis. At the most elementary level, there is a(nother) baseline problem. Intellectual property law creates rights to exclude, not to exploit. The lack of a paying market does not signal a violation of TRIPS. Nor does it identify a transfer of wealth: no one experiences a loss when products are distributed at cost to those without the means to pay supracompetitive prices. ${ }^{35}$ More generally, the GATT (and TRIPS) is intended to change over time, to reflect new needs and political realities. It would be particularly perverse to read the GATT as preventing the African nations from jump-starting regionalization when Europe has several members whose own prosperity is directly traceable to a similar effort, an effort that was pursued at a time when it was thought by some to be in violation of GATT obligations. ${ }^{3 .}$

Most importantly, the notion that members "consented" to the current Agreement is specious. Unlike former versions of the GATT, the Uruguay Round required nations to agree to every instrument. Those in need of markets for raw and manufactured products had little choice but to sign on to TRIPS, no matter how antithetical intellectual property law

35 Compare Brown v Legal Foundation of Washington, 123 S Ct 1406, 1419-20 (2003) (holding that legal clients do not experience a compensable taking when the interest from escrow accounts is used for legal aid because "any pecuniary compensation must be measured by ... net losses rather than the value of the public's gain").

36 See Lowenfeld, Public Controls on International Trade \$\$ 3.11-3.13 (cited in note 5) (calling recognition of the European Economic Community a "de facto renegotiation" of the GATT). 
was to their needs. Thus, as a procedural matter, joining TRIPS should be seen as more coercive than consensual. ${ }^{37}$

Substantively, the unconscionability of the "deal" is equally evident. Free trade is premised on a theory of comparative advantage. World wealth grows when each nation specializes in what it does best. On the whole, however, comparative advantages are amenable to change. The decision to forgo the manufacture of, say, automobiles is not permanent. Should a nation decide it no longer wishes to rely on foreign supply, or should the market for motor vehicles grow more lucrative, there is nothing in the GATT to prevent the citizens of that nation from entering the automobile sector. ${ }^{\text {ix }}$ The same is not true of intellectual property. Innovation is knowledge-intensive. Educating a citizenry to the level where it is technically and culturally sophisticated enough to innovate at globally competitive levels may become prohibitively expensive once intellectual property rights are recognized. Thus, unless some concession is made to user interests, any nation that is now behind will likely stay there. ${ }^{3 .}$

The countries that joined TRIPS may not have foreseen this problem. The rhetoric at the time was that intellectual property protection made a country safe for technology transfer, that recognizing these rights would attract foreign investments in local infrastructure and human capital." But that has not happened. Turn-key plants move from one country to another, depending on the cost of labor. In addition, commodification and subsequent importation of intellectual property-intensive products can put local manufacturing facilities out of business." TRIPS, in short, deprives developing countries of the ability to use the precise strategies that developed countries followed on their paths to prosperity. ${ }^{42}$ Changing

37 See Sell, Private Power, Public Law at 40 (cited in note 2) (explaining that the United States used access to its domestic markets to coerce "other countries into adopting and enforcing stricter IP policies").

38 For raw goods the analysis is different, as natural endowments do not change over time. However, markets for raw goods do change, so even here comparative advantages are not necessarily entrenched.

39 Another solution is to redefine intellectual property to include products that developing countries have to sell-folklore, folk remedies, and geographical indications. That effort is ongoing, but it is not likely to yield resources that will raise the prosperity of these countries significantly. See, for example, Rosemary J. Coombe, Intellectual Property, Human Rights \& Sovereignty: New Dilemmas in International Law Posed by the Recognition of Indigenous Knowledge and the Conservation of Biodiversity, 6 Ind J Global Legal Stud 59 (1998) (discussing ways in which the international intellectual property regime can better protect indigenous groups).

40 See, for example, Carlos Alberto Primo Braga, The Economics of Intellectual Property Rights and the GATT: $A$ View from the South, 22 Vand J Transnatl L 243, 260-61 (1989).

41 See, for example, Keith Aoki, Neocolonialism, Anticommons Property, and Biopiracy in the (Not-So-Brave) New World Order of International Intellectual Property Protection, 6 Ind J Global Legal Stud 11,52 (1998) (providing examples of "biocolonialism where resources and discoveries flow out of the Third World as 'raw materials,' only to return from the laboratories of the West as intellectual properties owned by foreign corporations").

42 The United States, for example, did not recognize foreign copyrights until it became a net exporter of copyrighted materials. In general, books published in English before 1986 were copy- 
the instrument would not effect a taking; it would right an unanticipated wrong.

\section{ThE CONTOURS OF USER RightS}

A few user rights can be found in the TRIPS Agreement itself. For example, Article 9(2) prohibits the extension of copyright to "ideas, procedures, ... and such," and Article 10(2) limits database protection "to the data itself." the principles underlying these provisions to other intellectual property areas, to create, for example, a distinction between an idea and its embodiment in a patented invention. ${ }^{4}$ However, focusing overmuch on existing provisions could equally raise the argument that they are the only substantive limitations possible. ${ }^{\text {t5 }}$ Thus, if one posits that user rights should be added, it is important to broaden the search.

One might think that it would be easy to compile a wish list of user rights. After all, American academics have spilled much ink on questions of user access to intellectual property. A moment's thought reveals, however, that the task is not so straightforward: core protections for users are, on the whole, not found in intellectual property laws themselves, but rather in other law or, more obscurely, embedded in the structure of the legal regime as a whole. Indeed, for developing countries, this is an important part of the problem. Because these states lack the background rules that developed countries take for granted, the bases for limiting the scope of rights, or for implying user protections into law, are largely absent. For that reason, examining the provisions of the law in developed countries that generate protections for users is a helpful step.

As to American law, the First Amendment is a good place to begin. Although not often cited in intellectual property decisions, free speech guarantees form a backdrop to judicial consideration of several important intellectual property issues. ${ }^{\text {th }}$ For example, the idea/expression dichotomy in copyright law and the fair use provision in copyright and trademark

rightable only if they were manufactured in North America. See 17 USC $\S 601$ (2000). Both of these strategies are now prohibited by TRIPS. See Sell, Private Power, Public Law at 9 (cited in note 2) (explaining that the development path of industrialized nations, involving the appropriation of others' intellectual property, is now barred to indust rializing countries by TRIPS); Thomas Bender and David Sampliner, Poets, Pirates, and the Creation of American Literature, 29 NYU J Intl L \& Polit 255 (1996-1997) (analyzing how early U.S. copyright law and the widespread practice of piracy of intellectual property contributed to the development of American cultural industries).

43 TRIPS Arts 9(2), 10(2) at 325 (cited in note 1).

44 Consider Funk Brothers Seed Co v Kalo Inoculant Co, 333 US 127, 131 (1948) (holding that products of nature are not statutory subject matter); $O^{\prime}$ Reilly $v$ Morse, 56 US (15 How) 62, 114 (1853) (holding that abstract principles are not patentable subject matter).

45 Consider, for example, Tennessee Valley Authority $v$ Hill, 437 US 153, 188 (1978) (relying on the maxim expressio unius est exclusio alterius to interpret the Endangered Species Act).

46. See generally Neil Weinstock Netanel, Locating Copyright within the First Amendment Skein, 54 Stan L Rev 1 (2001). 
law are generally interpreted in a manner that avoids the need for constitutional adjudication. In patent law, certain subject matter restrictions may have a similar effect." Moreover, the longstanding norm against suing academics for patent infringement may be interpreted as deference to a principle of academic freedom or a right to experiment. Analogously, the penumbral rights to privacy evoked by combining the First Amendment with other constitutional guarantees may help explain the preference for bringing contributory infringement and vicarious liability suits over direct actions against private copying ${ }^{48}$ or the limitation of performance and display rights to public activities. Such considerations may also provide the impetus for an expansive view of what constitutes fair use in the private arena." Reconceptualized, these laws, norms, and traditions argue for rights of access to, and use of, core scientific principles, factual material, and features of nature - that is, to "pure knowledge about the physical world." ${ }^{\text {s1 }}$ They also suggest that certain uses should be privileged: those with high spillover benefits (such as scholarship and research), and perhaps even certain activities (such as copying) that are carried out for purely private use.

Although the First Amendment is the background rule that most American observers would consider first, some commentators in developing countries are more troubled by the absence of antitrust laws. The TRIPS Agreement recognizes that members may need law to control the abuse of intellectual property rights, ${ }^{33}$ but countries that did not have enforceable intellectual property laws prior to joining the WTO had little reason to develop competition law to control right holders. Thus, for ex-

47 See, for example, Richard S. Gruner, Intangible Inventions: Patentable Subject Matter for an Information Age, 35 Loyola LA L Rev 355, 371-72 (2002); Dan L. Burk, Software as Speech, 8 Seton Hall Const L J 683, 690 (1998); Diane Zimmerman, Scientific Speech in the 1990s, 2 NYU Envir L J 254, 260-61 (1993); Gary L. Francione, Experimentation and the Marketplace Theory of the First Amendment, 136 U Pa L Rev 417 (1987).

48 Compare $A \&$ \& M Records, Inc v Napster, Inc, 239 F3d 1004 (9th Cir 2001) (involving claims against Napster for contributory and vicarious copyright infringement), with In re Verizon Internet Services, Inc, 257 F Supp 2d 244 (D DC 2003) (involving the subpoena of an Internet Service Provider for names of users who allegedly engaged in private copying), revd, Recording Industry Association of America, Inc v Verizon Internet Services, Inc, 2003 US App LEXIS 25735 (DC Cir 2003).

49 See 17 USC $\$ 106(4)-(5)(2000)$ (providing for the copyright owner's exclusive right to show a protected work in public).

50 See, for example, Sony Corp of America v Universal City Studios, Inc, 464 US 417 (1984) (holding that home recording of commercial broadcasts constitutes fair use).

51 Royal Society, Keeping Science Open: The Effects of Intellectual Property Policy on the Conduct of Science $\$ 3.5$ (2003), online at http://www.royalsoc.ac.uk/files/statfiles/document-221.pdf (visited Jan 12, 2004) (urging that "requirements for inventive step and industrial applicability" be applied with greater rigor).

52 See id $\$ 3.23$ (recommending that governments consider "clarifying and harmonizing" existing exceptions for noncommercial research).

53 See TRIPS Art 8.2 at 324 (cited in note 1). See also id Art 31(k) at 335 (permitting the use of patented subject matter without authorization when needed to remedy anticompetitive practices); id Art 40 at 338 (authorizing members to legislatively combat anticompetitive licensing). 
ample, at a recent conference, a participant from the Philippines claimed that nonpatented seeds are difficult to purchase there because patent holders regularly impose exclusive-dealing requirements: sellers must agree not to sell the goods of rival suppliers. Even in developed economies, the appropriate balance between intellectual property rights and competition law is never entirely certain, ${ }^{\text {,4 }}$ which makes the articulation of positive limits on what patentees can do universally desirable.

Some have suggested that because most patentees come from developed countries, anticompetitive conduct could be constrained by allowing users in developing countries to sue in the patentee's home court, claiming that its actions violate the law of the forum. ${ }^{\text {ss }}$ That approach would clearly bring developed competition law into play and eliminate some of the need to create legal infrastructure in developing countries. However, because the law in developed countries is not always clear, and because law is usually applied extraterritorially only in the unusual situation in which conduct has far-flung effects, this procedure is not likely to reach any but the most egregious situations. There are also those who would add antitrust law to the WTO's agenda (often, for reasons having to do with trade distortion and not intellectual property policy), but that too appears to be a rather remote eventuality. Instead, the WTO's commitment to intellectual property could be exploited by amending TRIPS to create user rights that limit the power of right holders in ways that mimic the effect of competition laws. For instance, rights could be articulated to protect participants in secondary markets (a right to refurbish patented products, or a right to deal in patented parts). To the extent that the problem in developing countries is inappropriate leveraging of patent rights, the United States and European Union guidelines on intellectual property licensing are useful resources. ${ }^{\text {sh }}$ Thus, one could envision a right to be free of unreasonable (or anticompetitive) exclusive dealing arrangements, tie-outs, grant backs, and the like.

54 Compare In re Independent Service Organizations Antitrust Litigation, 203 F3d 1322, 1327-28 (Fed Cir 2000) (upholding a patentee's refusal to license patented parts against an antitrust challenge), with Image Technical Services, Inc v Eastman Kodak Co, 125 F3d 1195, 1218-20 (9th Cir 1997) (finding a patentee's refusal to license parts a violation of the Sherman Act).

55 See, for example, Aaditya Mattoo and Arvind Subramanian, Multilateral Rules on Competition Policy-A Possible Way Forward, 31 J World Trade 95, 110-12 (Oct 1997) (proposing broadening the "definition of interested parties who can access domestic enforcement procedures"); Empagran S.A. v F. Hoffman-LaRoche, Ltd, 315 F3d 338,345-46 (DC Cir 2003) (holding that federal courts have jurisdiction over suits by foreign plaintiffs alleging injury from anticompetitive conduct in foreign commerce so long as the effects on U.S. commerce give rise to a claim under the Sherman Act), cert granted, 124 S Ct 966 (2003).

56 See United States Department of Justice and the Federal Trade Commission, Antitrust Guidelines for the Licensing of Intellectual Property (Apr 1995) (outlining the U.S. approach to anticompetitive licensing); Commission Regulation 240/96 of 31 January 1996 on the Application of Article 85(3) of the Treaty to Certain Categories of Technology Transfer Agreements, 39 Off J Eur Communities (L 31) 2 (Feb 9, 1996) (laying out the European Community's approach to various anticompetitive practices in the context of intellectual property enforcement). 
Purely structural protections for user interests may be unique to the United States. They include sovereign immunity and preemption doctrine. The former, which is based on the Eleventh Amendment, apparently permits state universities to make some unauthorized uses of protected works." Although such uses technically violate intellectual property laws, states are immune to actions for damages in federal court, the only place where patent and copyright infringement actions can be brought. ${ }^{\text {sx }}$ Of course, long-term usage could be stopped with an action for injunctive relief. ${ }^{54}$ However, some forms of intellectual property - biotech research targets, for example - can be fully exploited through brief usage, making an injunction irrelevant. The flexibility that sovereign immunity gives to state institutions could be duplicated in TRIPS by recognizing rights for special users, such as those engaged in socially important activities or those that cannot internalize enough of the benefits that flow from protected works to pay for their usage of them. Such rights would also be useful in developed countries that lack structural immunities. They would, incidentally, help put private universities in the United States back on an equal footing with public institutions.

In the United States, preemption doctrine plays an even more important role in protecting users because it acts as a cap on certain kinds of expansion of intellectual property rights. It controls the extent to which states can recognize exclusive rights outside the bounds set by federal intellectual property legislation." As important, it prevents states from achieving that result indirectly through the enforcement of contracts that undermine the user protections now in place." As with antitrust law, the exact scope of preemption is unclear. ${ }^{62}$ Nonetheless, some general princi-

57 See Florida Prepaid Postsecondary Education Expense Board v College Savings Bank, 527 US 627 (1999) (holding unconstitutional legislation that would abrogate states' sovereign immunity and allow parties to sue a state educational entity for patent infringement); College Savings Bank v Florida Prepaid Postsecondary Education Expense Board, 527 US 666 (1999) (holding unconstitutional legislation that would abrogate states' sovereign immunity and allow parties to sue a state educational entity for trademark infringement). See also 28 USC $\$ 1498$ (2000) (permitting unauthorized use of patented materials "by and for the United States," subject to a right to just compensation).

58 See 28 USC $\$ 1338$.

59 See Ex parte Young, 209 US 123 (1908) (holding that federal courts can enjoin state officers from enforcing unconstitutional laws); College Savings Bank, 527 US at 704 (Breyer dissenting) (arguing that the application of Ex parte Young might be appropriate to enjoin the state from trademark infringement).

6) See, for example, Bonito Boats, Inc v Thunder Craft Boats, Inc, 489 US 141, 141, 157 (1989) (finding that a Florida state statute that prohibited use of a process to duplicate unpatented boat hulls was preempted by a federal patent statute).

61 See, for example, Brulotte $v$ Thys Co, 379 US 29, 31 (1964) (invalidating contracts that prolong royalty payments beyond the patent term).

62 See, for example, Bowers v Baystate Technologies, Inc, 320 F3d 1317, 1324-25 (Fed Cir 2003) (enforcing a contract that prohibited reverse engineering); ProCD, Inc v Zeidenberg, 86 F3d 1447, 1449 (7th Cir 1996) (enforcing a contract that arguably voided the first sale doctrine and the Copyright $\mathrm{Act}$ ). 
ples can be discerned. For example, copying unprotected material is presumptively privileged, ${ }^{\mathrm{n}, 3}$ and there is a right to be free of a demand for royalties when the term of protection ends. ${ }^{\text {th }}$

In addition to these structurally based principles, legislation enacted recently enough to be attuned to the problems of fluctuating background norms and traditions is another source of user rights. For example, the European Software Directive includes the right to make a back-up copy; the right to observe, test, or study a computer program; the right to test for error correction; and the right to "decompile" or reverse engineer." Similarly, the European Database Directive includes the right to perform acts inherent to normal usage and the right to re-utilize substantive parts of a database. In some cases, these rights come with explicit rules about whether the user protections can be varied by contract. ${ }^{67}$ By the same token, it is worth comparing the traditional intellectual property regimes of developed countries to find commonalities (such as fair use and fair dealing) that are not currently phrased as affirmative rights, and that may not reflect identical guarantees, but that nonetheless assure that users have access to innovations.

Beyond these sources, it is up to those studying innovation to formulate positive law to protect the development of knowledge and the equitable distribution of its fruits. The Royal Society has recently proposed several user-protection principles. It would ensure adequate supplies of medicines in the case of pandemics and poverty, coupling that commitment to a method for preventing the backflow of these supplies to markets that can afford to pay. ${ }^{* *}$ As to both developing and developed economies, the Royal Society also suggests that there may be something of a right to be free of improperly issued patents. Thus, while many observers see patent examination as an administrative task, governed by rationality principles, ${ }^{19}$ the Royal Society stresses the key role that examination plays in protecting the public domain."

63 See text accompanying note 20.

64 See Lear, Inc v Adkins, 395 US 653, 671-74 (1969) (stating that enforcing a contractual provision extending royalties beyond patent expiration would undermine federal policy favoring the "full and free use of ideas in the public domain"). See also David E. Shipley and Jeffrey S. Hay, Protecting Research: Copyright, Common-Law Alternatives, and Federal Preemption, 63 NC L Rev 125 (1984) (discussing the problem of federal preemption of intellectual property contracts).

65 Council Directive 91/250 of 14 May 1991 on the Legal Protection of Computer Programs, Arts 5(1)-(3), 6,9(1), 34 Off J Eur Communities (L 122) 42,44-45 (May 17,1991). See also Amelia H. Boss, Taking UCITA on the Road: What Lessons Have We Learned?, 7 Roger Williams U L Rev 167, 205-06 (2001) (discussing rights that cannot be waived by contract under European law).

66 Directive on the Legal Protection of Databases, Arts 6(1), 8, 39 Off J Eur Communities ( $\mathrm{L}$ 77) at 25-26 (cited in note 27).

67 See Samuel K. Murumba, The Emerging Law of the Digital Domain and the Contract/IP Interface: An Antipodean Perspective, 26 Brooklyn J Intl L 91, 103-07 (2000) (discussing the use of contract to augment or supplement traditional intellectual property rights in Australia).

68 Royal Society, Keeping Science Open $\$ 3.43$ (cited in note 51).

69 See, for example, Mark A. Lemley, Rational Ignorance at the Patent Office, 95 Nw U L Rev 
Interestingly, the Royal Society Report also suggests that user interests could run to nations, rather than to individuals. Thus, it would tie a member state's TRIPS obligations to TRIPS benefits by delaying the duty to implement the Agreement until the time that the member state could enjoy its incentive effects." On a similar note, now that it has become clear that commodification can lead to importation rather than domestic manufacture, the wisdom of working rules, which are currently prohibited by TRIPS, should be reevaluated.

The bottom line is this: it will not be easy for users to strike back and release TRIPS from its one-way ratchet in a manner acceptable to nations of varied interests in intellectual property. But until observers begin to focus on the problem of identifying the rights that are needed if intellectual progress is to continue to flourish, a well-reasoned debate cannot begin. It is, accordingly, time to start compiling a list.

70 Royal Society, Keeping Science Open $\$ 3.28$ (cited in note 51).

71 Id $\$ 3.44$. 


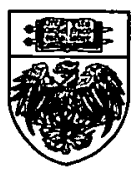

